\title{
Oceanographic settings explain fluctuations in Dinophysis spp. and concentrations of diarrhetic shellfish toxin in the plankton community within a mussel farm area on the Swedish west coast
}

\author{
Anna Godhe ${ }^{1, *}$, Susanne Svensson ${ }^{2}$, Ann-Sofi Rehnstam-Holm ${ }^{3}$ \\ ${ }^{1}$ Marine Botany, Department of Marine Ecology, Göteborg University, Box 461, 40530 Göteborg, Sweden \\ ${ }^{2}$ Department of Zoophysiology, Göteborg University, Box 463, 40530 Göteborg, Sweden \\ ${ }^{3}$ Clinical Bacteriology, Göteborg University, Guldhedsgatan 10, 41346 Göteborg, Sweden
}

\begin{abstract}
The influence of hydrographic, biological and meteorological variables on the abundance of Dinophysis spp. and the concentration of diarrhetic shellfish toxin (DST) in the plankton population were investigated in a mussel (Mytilus edulis) farm area on the Swedish west coast. This location provided an opportunity to simultaneously compare Dinophysis spp. cell numbers, concentration of DST in natural phytoplankton assemblages and toxicity of mussel tissues. Sampling was performed every other day from October 10 to November 5, 2000, and on each occasion, 5 randomly selected sites were sampled. During this period, 3 distinct water masses passed through the vicinity of the mussel farm. The second water mass, characterized by low salinity and nitrogen concentration, was probably advected into the area from surface waters in the nearby Skagerrak. This low salinity water also contained a high abundance of Dinophysis spp., and high concentrations of DST were recorded in the phytoplankton population. Multivariate analysis (projection to latent structures by means of partial least squares, PLS) determined that the principal variables influencing the concentration of DST in the plankton assemblage were the causative species (D. acuminata, D. acuta and $D$. norvegica) and salinity. The abundance of the 3 Dinophysis spp. was inversely correlated to salinity. A rapid increase in the toxicity of mussels in response to the high levels of DST was observed. The concentration of DST had doubled within $2 \mathrm{~d}$ of the appearance of Dinophysis spp. After $8 \mathrm{~d}$, the water mass containing Dinophysis spp. was replaced and cell numbers again returned to low levels. The concentration of DST in the phytoplankton samples remained high for another $2 \mathrm{~d}$ after the number of Dinophysis spp. had declined and the toxicity of mussels continued to be high for the remainder of the study. Causes of the rapid intoxication versus slow detoxification of mussels are discussed. These results suggest that present monitoring programs are insufficient to provide early warning of toxic blooms to aquaculturists on the Swedish west coast.
\end{abstract}

KEY WORDS: Diarrhetic shellfish toxin · DST - Dinophysis spp. · Mytilus edulis · Skagerrak · Environmental variables $\cdot$ PLS

\section{INTRODUCTION}

Blooms of Dinophysis spp. and related outbursts of diarrhetic shellfish poisoning (DSP) through ingestion of mussels or other shellfish are reported worldwide.

*E-mail: anna.godhe@marbot.gu.se
These incidents cause human health hazards and great economic losses in the aquaculture industry every year (Hallegraeff 1995). Elevated levels of diarrhetic shellfish toxins (DSTs) in blue mussels Mytilus edulis Linnaeus have been recorded along the Swedish west coast every year since 1983, when the first outbreaks of DSP were reported (Haamer et al. 1990a, Lindahl \& Andersson 1996). Concentrations of DST in mussels 
are normally low from March to August and high from October to January. In some years, farms are closed for harvest for 6 mo or more, whereas in other years there is just a very short interruption of the harvest (Haamer 1995, Lindegarth 1997). Consequently, DST has been identified as the largest impediment to further development of mussel farming in Sweden (Kollberg 1999).

DSTs are produced by species belonging to the genera Dinophysis Ehrenberg and Prorocentrum Ehrenberg (Yasumoto et al. 1980, Murakami et al. 1982). This family of toxins consists mainly of okadaic acid (OA) and structurally related dinophysistoxins (DTXs) (Yasumoto et al. 1985, Kumagai et al. 1986, Carmody et al. 1996). DSTs are potent protein phosphatase inhibitors, subsequently causing a dramatic increase in phosphorylation of numerous proteins resulting in diarrhoeic effects, as well as being potent tumour promoters (e.g. Fujiki et al. 1988, Daranas et al. 2001).

Information about the relationships between environmental influences, growth and production of toxins in Dinophysis is scarce and understood only to a minor degree. This is in part due to the lack of knowledge on how to cultivate Dinophysis spp. (Sampayo 1993), reducing the possibilities for controlled experiments. Observations in mesocosms have shown that the production of toxins increased in $D$. acuminata Claparède et Lachmann when nitrogen or phosphate was limited, whereas D. acuta Ehrenberg had the highest production of toxins when nutrient concentrations were balanced (Johansson et al. 1996). For other species of microalgae, laboratory experiments have shown that the production of toxin changes in response to fluctuations of macronutrients, light intensity, $\mathrm{pH}$ and salinity (e.g. Granéli et al. 1998, Song et al. 1998, John \& Flynn 2000, Hamasaki et al. 2001).

There are papers describing Dinophysis spp. abundances in relation to different environmental conditions (e.g. Soudant et al. 1997, Blanco et al. 1998, Aubry et al. 2000, Smayda \& Reynolds 2001). Large spatial scale sampling at shorter or longer intervals, sampling of 1 site with high temporal resolution, or analyses of several years of monitoring data over a vast area constitute the data sets investigated in these papers. Models based on data of dinoflagellate growth and different environmental parameters collected at less frequent intervals or on a great geographic scale may exhibit certain drawbacks. Any correlations in models based on weekly or monthly collected data between, for instance, nutrients and algal biomass reflect the immediate relation between the two, and not what has been present just previously in terms of nutrients and what could possibly have promoted dinoflagellate growth.

The purpose of this study was to (1) investigate which environmental variables correlate with the abundance of Dinophysis spp. and the toxicity of the plankton community; this was done by sampling at a high temporal resolution and using a multivariate approach $_{i}(2)$ investigate if fluctuations in DST concentration of the plankton community versus the Dinophysis spp. abundance (an assumed DST content per cell) and the cause of such fluctuations can be detected in field observations; and (3) examine the temporal scale between peaks of DST in the plankton community and in mussel tissue. Therefore the study was performed in the vicinity of a mussel farm. The main advantage of this study was the sampling strategy, designed to cover any small-scale spatial heterogeneity such as patchy distribution of algal cells or nutrients in the area around the mussel farm. This paper provides a more complete picture of environmental parameters, toxicity of phytoplankton and shellfish in order to see how well these parameters correlate in the field.

\section{MATERIALS AND METHODS}

Study area. The sampling sites were located in the Nycklebyviken, between the islands of Tjärnö and Öddö, on the northern part of the Swedish west coast (Fig. 1). The area is a channel in the east-west direction and has many small islands. Outside the channel is the deep Kosterfjord (ca. $250 \mathrm{~m}$ ), which is open to the Skagerrak at both ends. Two major current systems affect the Skagerrak coastal area: the low saline surface Baltic current running north parallel to the coast, and the central Skagerrak water circulation pattern resulting in an inflow of more saline North Atlantic water. Hence, the coastal water is stratified in terms of salinity and a pronounced halocline is present (Rodhe 1987, Lindahl 1995). Within Nycklebyviken is a blue mussel farm of approximately $4500 \mathrm{~m}^{2}$ (Fig. 1A). The water depth of the area is 10 to $18 \mathrm{~m}$. The predominant current directions in the studied area are WNW $\left(297^{\circ}\right)$ or ESE $\left(117^{\circ}\right)$. The currents inside the channel are dominated by the tidal contribution, although the tides in the area only have an amplitude of about $0.3 \mathrm{~m}$. Consequently the main current will change its magnitude and direction every $6 \mathrm{~h}$ in accordance with water level changes. The tidal currents are however too weak to cause any noticeable intrusion of new water into the area, either from the shallow interior or from the Skagerrak. Also, the river discharges are usually too small to affect the currents. Exchange of water and higher current velocity is caused by the additional effect of local winds and differences in atmospheric pressure. Changes in hydrographical parameters such as water currents, temperature, salinity, dissolved oxygen and inorganic nutrients in the channel have to some extent been attributed to seasonal cycles. How- 


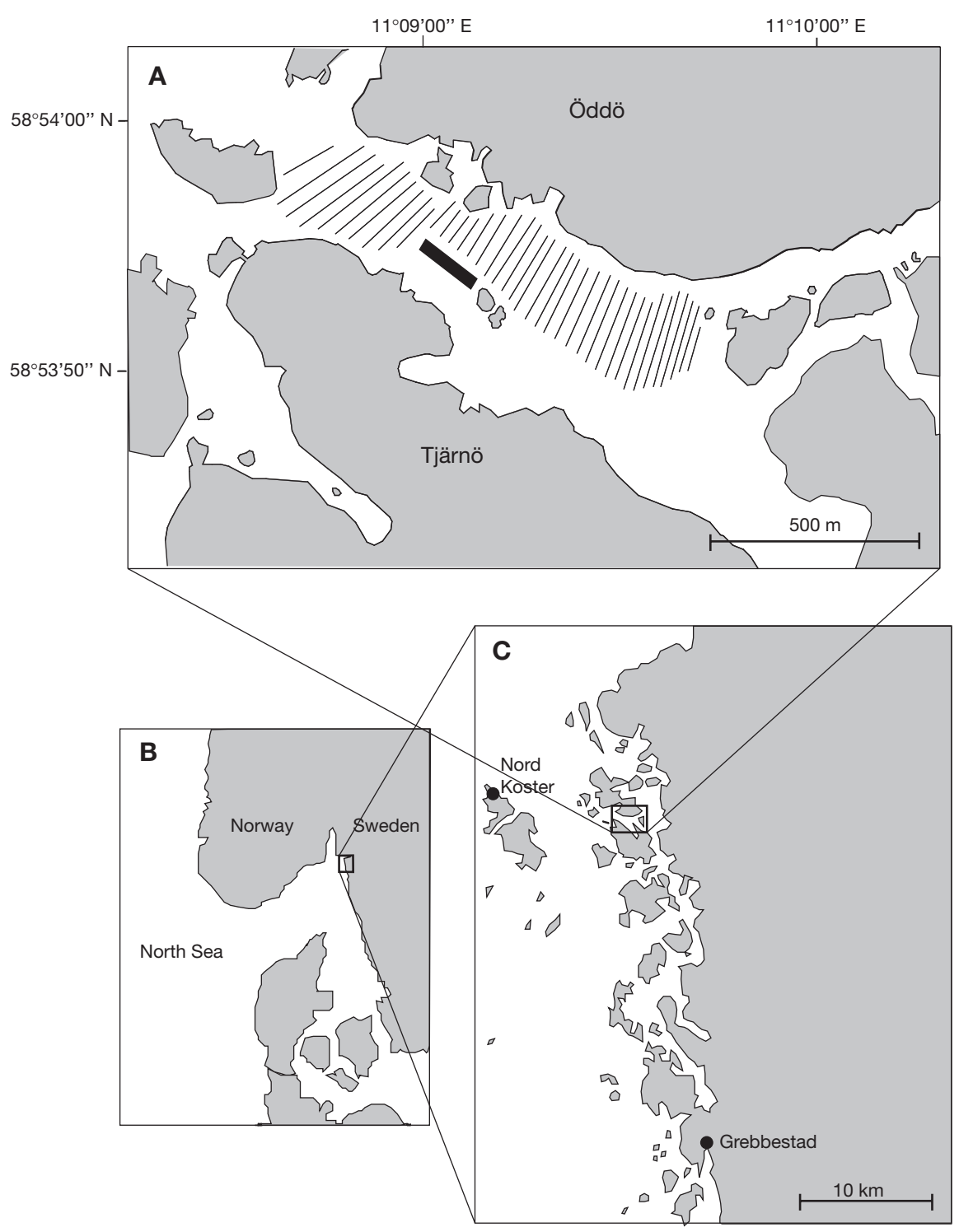

Fig. 1. (A) Nycklebyviken, Swedish west coast. The location of the blue mussel farm is marked with a black bar, and the area of the 45 potential sites for water measurements and collection is striped (see text for further details). (B) South Scandinavia. (C) Northern west coast of Sweden. Meteorological data were acquired from Nord Koster and Grebbestad (see text for further details)

ever, greater and more rapid changes in the same parameters are caused by changes of water masses in the area (Larsson 1984, 1986).

Previous studies have shown that colonies of Mytilus edulis may affect the immediate vicinity in respect to inorganic nutrients, especially $\mathrm{NH}_{4}{ }^{+}$and $\mathrm{PO}_{4}{ }^{3-}$ (Kautsky \& Wallentinus 1980). This particular area has previously been investigated in order to reveal the effects of blue mussel sea farming on water quality. Elevated concentrations of inorganic nutrients were rare and were detected only in the summer season at low current velocity (Larsson 1986). We confirmed this result by analyses of inorganic nutrients of water samples collected along 3 separate transects of 0 to $200 \mathrm{~m}$ dis- tance from the farm in a pilot study prior to October 10, 2000 (data not shown). Even though no elevated nutrient concentrations were detected along the transects in our pilot study, no water samples were taken closer than $10 \mathrm{~m}$ to the farm. In order to avoid contact with the bottom, no water samples were taken at a greater depth than $8 \mathrm{~m}$. The field study was conducted during the period October 10 to November 5, 2000. Forty-five potential sites for water measurements and collection were selected $\left(58^{\circ} 53^{\prime} 57^{\prime \prime}\right.$ to $58^{\circ} 53^{\prime} 82^{\prime \prime} \mathrm{N}, 11^{\circ} 08^{\prime} 48^{\prime \prime}$ to $11^{\circ} 09^{\prime} 60^{\prime \prime} \mathrm{E}$ ) and marked on a nautical chart. The selection of these 45 sites within the area was made with regard to the depth and the location of the mussel farm (Fig. 1A). Five positions for collection of water 
samples and other measurements (see below) were randomly selected among the 45 potential sites every $2 \mathrm{~d}$ by the function 'Random' in Excel (Microsoft).

Sample collection. Water samples were collected every $2 \mathrm{~d}$ at 5 randomly selected sites as described above. Immediately after reaching each site the boat was anchored and the exact position was obtained by Global Positioning System (GPS). Samples for nutrient analysis $\left(\mathrm{NO}_{2}{ }^{-}, \mathrm{NO}_{3}{ }^{-}, \mathrm{NH}_{4}{ }^{+}, \mathrm{SiO}_{2}\right.$ and $\left.\mathrm{PO}_{4}{ }^{3-}\right)$ were collected from 3 and $8 \mathrm{~m}$ using an allplastic $1.6 \mathrm{l}$ Ruttner water bottle. From each depth, $5 \mathrm{ml}$ in duplicate were collected with syringes and filtered through disposable syringe filters $(0.45 \mu \mathrm{m}$ membrane filter Sartorius MiniSart NML) into polycarbonate test tubes. The test tubes were stored at $-80^{\circ} \mathrm{C}$ within $3 \mathrm{~h}$ until analysis on a TRAACS 2000 autoanalyzer within 1 mo (Grasshoff et al. 1983). Salinity and water temperature were measured in the field from the same depths with a hand refractometer (Atago S-10) and thermometer, respectively.

Water samples for Dinophysis spp. identification and enumeration, and chlorophyll a ( $\mathrm{chl}$ a) measurements were collected with a pump (12 $1 \mathrm{~min}^{-1}$, hose diameter $20 \mathrm{~mm}$ ). The hose connected to the pump was moved up and down through the water column (0 to $8 \mathrm{~m}$ ) while pumping. The water from the 0 to $8 \mathrm{~m}$ layer was collected into a bucket and mixed. From the bucket, $500 \mathrm{ml}$ was transferred to a polyethylene bottle for chl a analysis, and $500 \mathrm{ml}$ in duplicate for Dinophysis spp. enumeration was fixed in $1 \%$ acid Lugol's solution (Willén 1962).

From every station, 40 to 801 of water was pumped for analyses of DST by protein phosphatase inhibition assay (PPIA). The hose was moved up and down through the water column ( 0 to $8 \mathrm{~m}$ ) while pumping and the water was emptied into a $10 \mu \mathrm{m}$ plankton net. After pumping was finished, the content of the net was emptied into $50 \mathrm{ml}$ Falcon tubes. In the laboratory, the tubes were centrifuged at $3000 \mathrm{rpm}(650 \times g)$ for $5 \mathrm{~min}$. The supernatant was discarded and the algal pellets were stored at $-80^{\circ} \mathrm{C}$ until analysis, which was done within 2 mo.

The direction and velocity of the currents were measured at 2 sites $\left(58^{\circ} 53^{\prime} 68^{\prime \prime} \mathrm{N}, 11^{\circ} 08^{\prime} 67^{\prime \prime} \mathrm{E}\right.$ and $58^{\circ} 53^{\prime} 60^{\prime \prime} \mathrm{N}, 11^{\circ} 09^{\prime} 13^{\prime \prime} \mathrm{E}$ ) and calculated using the displacement of drogues in time and space. This was done every $2 \mathrm{~d}$ at 2 different depths ( 2 and $7 \mathrm{~m}$ ) at each site. The drogues were discharged and the time and GPS position were recorded. After approximately $1 \mathrm{~h}$, the drogues were again collected and their new positions and the time were recorded.

Prior to starting the study, baskets containing mussels (length of mussels 6 to $8 \mathrm{~cm}$ ) collected from the farm were anchored within the mussel farm at 3 different depths (1,5 and $8 \mathrm{~m})$. Mussels Mytilus edulis were sampled every $2 \mathrm{~d}$ for analysis of toxins. Two replicate samples, each consisting of 12 mussels with 4 individuals from each depth, were taken on each sampling occasion. The mussels were frozen at $-20^{\circ} \mathrm{C}$ until analysis.

Chl $\boldsymbol{a}$ analysis. Water samples for chl a measurements $(2 \times 100 \mathrm{ml})$ were filtered on Whatman GF/F glass-fibre filters and frozen at $-80^{\circ} \mathrm{C}$ until analysis. $\mathrm{Chl}$ a was extracted in $5 \mathrm{ml} 100 \%$ methanol. Prior to analysis the samples were sonicated for $10 \mathrm{~s}$ with a Sonics Vibra Cell and filtered through a $0.22 \mu \mathrm{m}$ Cameo 25 syringe filter. Chl a concentration was measured with a Turner Fluorometer (Turner Design model TD-700). The fluorometer was calibrated using natural phytoplankton samples previously analysed spectrophotometrically according to Jeffrey \& Humphrey (1975).

Dinophysis spp. identification and enumeration. Fifty ml of Lugol's fixed plankton samples were settled in Utermöhl-type sedimentation chambers (Utermöhl 1958). After 12 to 24 h, Dinophysis spp. were counted and identified to species level at $200 \times$ and $400 \times$ magnification, using a Zeiss Axiovert 135 inverted microscope. A semi-quantitative record of other plankton taxa was noted in all samples.

Meteorological data. The data on atmospheric pressure, air temperature, direction and velocity of the wind were obtained from the monitoring station of the Swedish Meteorological and Hydrographic Institute (SMHI) at Nord Koster (Fig. 1C). Data on precipitation were obtained from the same institute at the monitoring station in Grebbestad (Fig. 1C).

Mussel toxicity analyses. Mussels were thawed and the digestive glands were dissected. Wet weights of the digestive glands and the rest of the soft tissues were determined. The digestive glands were then homogenized for $30 \mathrm{~s}$ using an Ultra-Turrax knife homogenizer at room temperature. The procedure for the sample clean-up followed the protocol for HPLC (high performance liquid chromatography) analysis described by Lee et al. (1987). The resulting chloroform extracts were used for detection of DST by the PPIA according to Vieytes et al. (1997).

The assay for analysis of DST was performed in 96 well microplates. The following buffers were used: (1) dilution buffer (DB), $50 \mathrm{mM}$ Tris- $\mathrm{HCl} \mathrm{pH} 7.0$ containing $0.1 \mathrm{mM} \mathrm{CaCl}_{2}$ (2) phosphatase assay buffer (PAB), DB containing $3 \mathrm{mM} \mathrm{NiCl}{ }_{2}$ (stock solution $40 \mathrm{mM}$ ) and $0.4 \mathrm{mg} \mathrm{ml}^{-1}$ BSA (stock solution $5 \mathrm{mg}$ $\mathrm{ml}^{-1}$ ); (3) PP2A buffer (PPB), protein phosphatase 2A (PP2A), $200 \mathrm{U} \mathrm{ml}^{-1}$ (Upstate Biotechnology) diluted in enzyme dilution buffer added to PAB to a final concentration corresponding to $0.02 \mathrm{U}$ of enzyme per well; (4) substrate buffer (SB), 4-methyl umbelliferyl phosphate (MUP) free acid in dimethyl sulphoxide (Sar- 
stedt) diluted in DB to a final concentration in the wells of $42 \mu \mathrm{M}$ MUP.

To calculate the concentration of DST in mussel and algal samples, a standard curve for OA was used. This was prepared by dissolving OA (LC Laboratories) in $80 \%$ methanol to a standard stock solution of $2 \mu \mathrm{g} \mathrm{ml}^{-1}$. The stock was then further diluted in DB to concentrations ranging from 0.2 to $0.005 \mu \mathrm{g} \mathrm{ml}^{-1}$, which was found to meet the linearity interval for $0.02 \mathrm{U}$ PP2A per well used in the assay.

A volume of $1 \mathrm{ml}$ of the mussel chloroform extract was evaporated and redissolved in $100 \mu \mathrm{l}$ of $100 \%$ methanol, and $900 \mu \mathrm{l}$ of DB was added. This initial extract was further diluted 3 times in order to fit the sample into the linear part of the standard curve. To a 96 well microplate, $35 \mu \mathrm{l}$ of $\mathrm{PAB}$ was added and the plate was left to stand for approximately $10 \mathrm{~min}$. Then $10 \mu \mathrm{l}$ of sample or OA standard was added in duplicate to the wells; $35 \mu$ of PPB was added and the plate was incubated for $15 \mathrm{~min}$ at $37^{\circ} \mathrm{C}$. Then, $120 \mu \mathrm{l}$ of MUP was added and the plate was left at room temperature in a dark place. After $1 \mathrm{~h}$, fluorescence was measured on a Victor multilable counter (Viktor 1420, Wallac) at excitation wavelength $385 \mathrm{~nm}$ and emission wavelength $405 \mathrm{~nm}$. Blanks for every sample were used in order to eliminate background effects. The concentration of DST in the samples was calculated by interpolation of the activity from the linear portion of the OA standard curve and expressed as $\mu \mathrm{g}$ OA equivalents $\mathrm{kg}^{-1}$ mussel meat ( $\mu \mathrm{g}$ OA eq $\mathrm{kg}^{-1}$ ).

Algal toxin analyses. Algal pellets were weighed and diluted $4 \times$ in $80 \%$ methanol. Thereafter the suspensions were vortexed for $30 \mathrm{~s}$ and sonicated for $5 \mathrm{~s}$ (Sonicator Cell Disruptor, model W-375, HeatsystemUltrasonic). The suspensions were centrifuged for $10 \mathrm{~min}$ at $4500 \mathrm{rpm}(1500 \times \mathrm{g})$ and the volume of the supernatant was determined and transferred to a fresh tube. Methanol was then evaporated at $45^{\circ} \mathrm{C}$ at constant airflow for 2 to $12 \mathrm{~h}$ depending on the initial volume. The inside of the test tubes were washed with $80 \mu \mathrm{l} 80 \%$ methanol and the tubes were put in an ultrasonication bath for $15 \mathrm{~min}$. Thereafter $720 \mu \mathrm{l}$ Trisbuffer was added.

PPIA for algal toxins was performed as described for mussel toxicity with the following exceptions: $20 \mu \mathrm{l}$ of each OA standard dilutions (0.2 to $0.005 \mu \mathrm{g} \mathrm{ml}^{-1}$ ) and samples were added to the wells, since the toxin concentration in the algal extracts were predicted to be low. However, the methanol content in the wells was still under $1 \%$, which is below the level at which the enzyme is affected (Vieytes et al. 1997). Four wells for each sample were used, 2 replicates and 2 negative controls where no enzyme was added. The concentration of DST in the samples was calculated as described for mussels and expressed as ng OA equivalents $1^{-1}$ seawater (ng OA eq $\mathrm{l}^{-1}$ ). Recovery tests and validation assays of the extraction method have shown equivalent results irrespective of assay used (i.e. HPLC or PPIA). These results will be reported elsewhere (B. Lundve \& A.-S. Rehnstam-Holm unpubl.).

Statistical analysis. In this study, the relationships between environmental variables, the concentration of DST in the plankton community and the causative species Dinophysis spp. have been investigated with projection to latent structures by means of partial least squares (PLS) analysis (Wold et al. 1984), using the software SIMCA-P 8.0 (UMETRICS). PLS is a generalization of regression based on latent variables for finding the linear or polynomial relationship between a set of predictor variables $(x)$ and a set of response variables or a single response variable $(y)$. PLS has some advantages over multiple linear regression: (1) PLS allows for the number of predictor variables to be greater than that of the objects. (2) PLS can use multitudes of correlated $x$-variables (multivariate colinear data) and tolerate certain amounts of missing data (Eriksson et al. 1999).

Concentration of DST (ng OA eq $\mathrm{l}^{-1}$ ) in the plankton community, and the 3 dominant Dinophysis species $\left(\right.$ cells $\mathrm{l}^{-1}$ ) were used as response variables in 4 separate models. The biological, hydrographic and meteorological parameters used as predictor variables are listed in Table 1 . The range and average value of the investigated parameters and the percentage of missing data for each and every parameter over the full data set are presented. All variables were centred and scaled to unit variance prior to analysis. Log-transformation of data prior to PLS analysis was tested. The obtained hierarchy of variables was the same after transformation, but the acquired components did not explain as much of the variation in the data set.

\section{RESULTS}

\section{General description of hydrography, meteorology and biology}

The water was stratified in terms of temperature and salinity in the beginning (October 10 to 16) and at the end (October 26 to November 5) of the study period (Fig. 2A,B). The pycnocline could be detected by sampling at 3 and $8 \mathrm{~m}$, except on October 18, 22 and 24

On October 10, when the study began, the water temperature was $14^{\circ} \mathrm{C}$ at $8 \mathrm{~m}$ and $13^{\circ} \mathrm{C}$ at $3 \mathrm{~m}$ (Fig. 2A). Salinity was 25 and 22 PSU at the same depths (Fig. 2B). The water had moderate salinity (median $24 \mathrm{PSU}$ ) and low $\mathrm{NO}_{2}^{-}-\mathrm{NO}_{3}{ }^{-}$(median $1.09 \mu \mathrm{M}$ ) concentration (Fig. 3). High density of Ceratium furca 


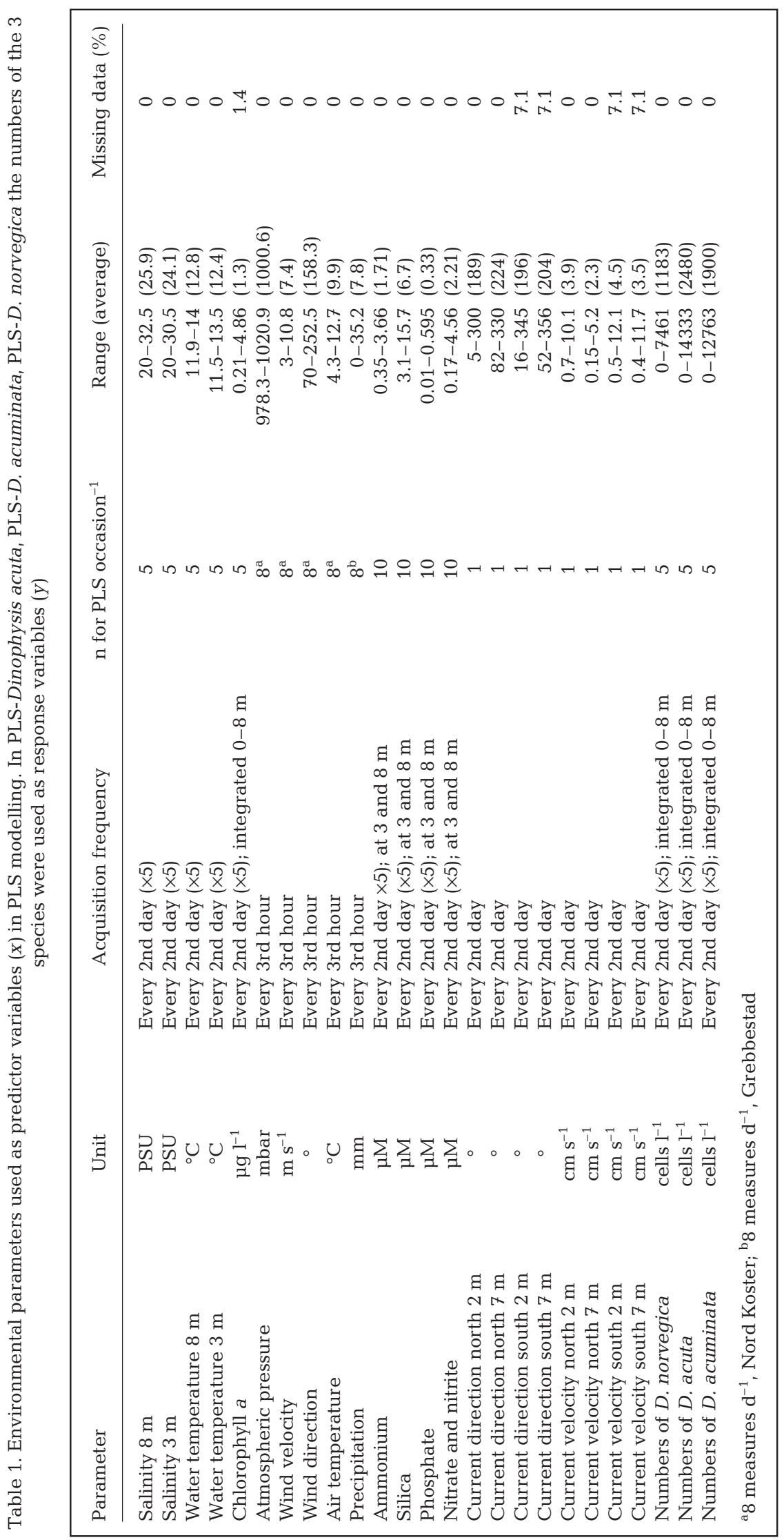

(Ehrenberg) Claparède et Lachmann and Pseudo-nitzschia spp. Peragallo caused high concentrations (maximum $4.8 \mathrm{\mu g} \mathrm{l}^{-1}$ ) of chl a (Fig. 2C). The cell numbers of these 2 taxa remained high until October 14, and then declined. The concentration of silica was highest during these first few days, up to $15 \mu \mathrm{mol} \mathrm{l}^{-1}$ (data not shown) and declined thereafter. The concentration of chl a declined from October 14 to the end of the investigated period (Fig. 2C).

Prior to October 18, the wind was SE to $\mathrm{S}$ (data not shown), resulting in less saline water being pushed up along the Swedish west coast by the Baltic current. The current in the studied area was NW at a velocity of 5 to $7 \mathrm{~cm} \mathrm{~s}^{-1}$. On October 18, a distinct new type of water entered the study area. This water had the character of surface water, displaying salinity below 23 PSU, and concentrations of $\mathrm{NO}_{2}^{-}-\mathrm{NO}_{3}^{-}$below $3 \mu \mathrm{mol} \mathrm{l}{ }^{-1}$ (Fig. 3). The pycnocline was not detected by the 3 and $8 \mathrm{~m}$ sampling (Fig. 2A,B), indicating a greater depth of the density barrier and hence an inflow of surface water from the Skagerrak. Together with this water, high abundances of primarily Dinophysis acuta, but also $D$. acuminata, $D$. norvegica Claparède et Lachmann and small

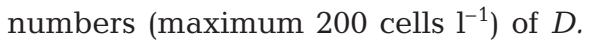
rotundata Claparède et Lachmann, $D$. hastata Stein and D. dens Pavillard, were encountered. This condition lasted $8 \mathrm{~d}$ with more than $12000 \mathrm{D}$. acuta cells $\mathrm{l}^{-1}$ (Fig. 2D). Prior to October 18, only low numbers of Dinophysis spp. were encountered (maximum average [n $=5$ ] October 10 to 16,2300 cells $1^{-1}$ ), which means that the growth could not have taken place within the area, but rather the peaks in cell density were a consequence of advection. This water mass remained in the studied area until October 26. By October 26, the wind direction had changed to NE and a new type of water substituted the surface water of the area. This water mass was characterized by bottom water which displayed high salinity (median 29.5 PSU) and high concentration (median $3.55 \mu \mathrm{M}$ ) of $\mathrm{NO}_{2}{ }^{-}-\mathrm{NO}_{3}{ }^{-}$(Fig. 3). Low concentration of chl a (range 0.21 

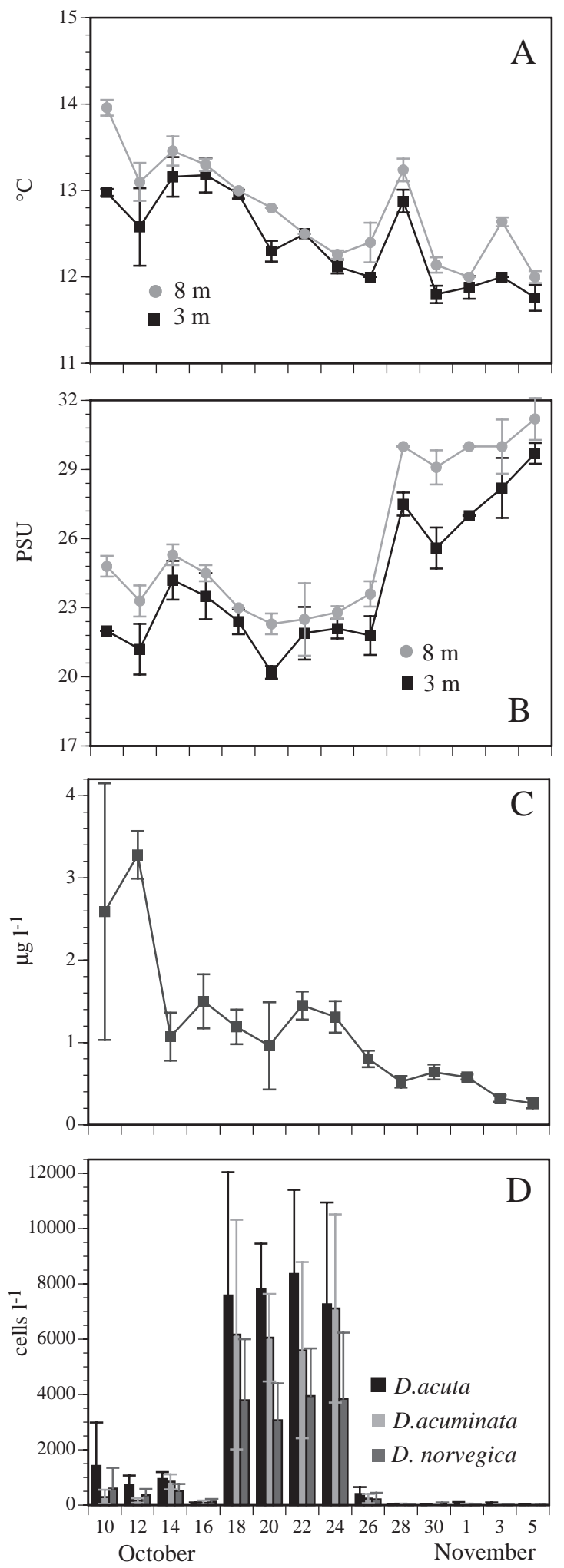

Fig. 2. Hydrography from October 10 to November 5, 2000, in Nycklebyviken. Error bars show the range of 5 replicate sites (SD). (A) Water temperature, (B) salinity, (C) chlorophyll $a$, (D) abundances of Dinophysis acuta, D. acuminata and D. norvegica

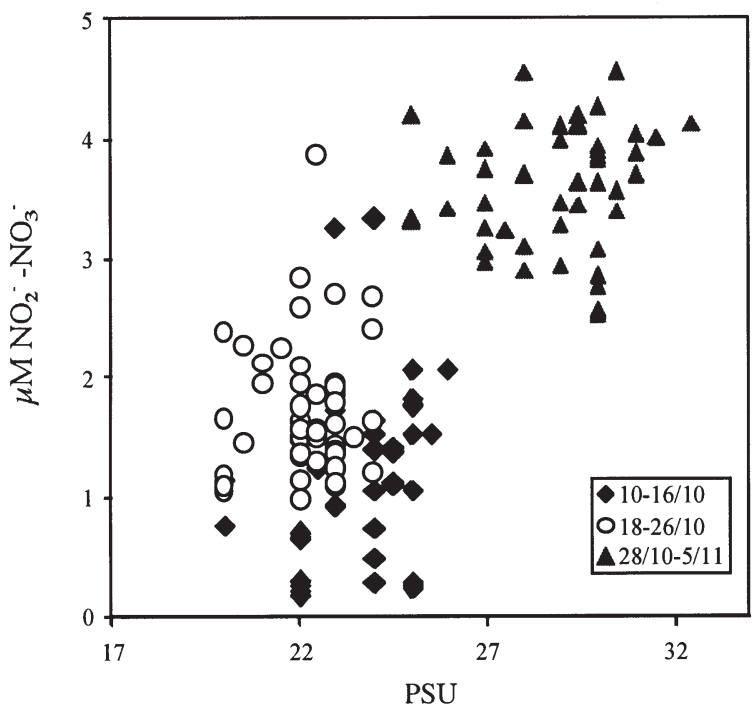

Fig. 3. Salinity/ $\mathrm{NO}_{2}{ }^{-}-\mathrm{NO}_{3}{ }^{-}$graph of all the sampled stations $(n=140)$. Five replicate sites were sampled at 3 and $8 \mathrm{~m}$ every second day during the period October 10 to November 5, 2000 (14 sampling occasions)

to $0.68 \mathrm{\mu g} \mathrm{l}^{-1}$ ) was detected and only few Dinophysis spp. cells $\mathrm{l}^{-1}$ (maximum average [n $=5$ ] October 28 to

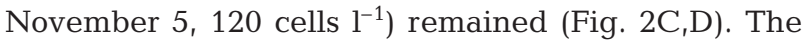
phytoplankton flora was meagre and comprised mainly diatoms (data not shown).

\section{Relationship between environmental parameters and algal toxins/Dinophysis spp.}

The PLS analyses in this experiment were significant as the $Q^{2}$ (cross-validated variance) statistics were larger than the limit in all 4 models (Table 2). The $Q^{2}$ for a significant model or for a component should be larger than a critical value, $Q^{2}$ limit $=0.097$, corresponding to $\mathrm{p}<0.05$. The 1 -component model for algal toxins as the response variable (PLS-DST, Table 2) explained $70.5 \%$ of the variation of DST recorded from the phytoplankton community. The predicted fraction of the variation of DST was $56.9 \%$, suggesting a good model. The variables with the highest influence on the model (VIP, variable influence on projection) and their respective regression coefficients are listed in Table 3. The DST-producing species Dinophysis acuta was the most important variable, tightly followed by 2 species of the same genus, $D$. norvegica and $D$. acuminata. The principal environmental variable influencing the concentration of algal toxins in this model was salinity. Salinity was inversely related to the concentration of DST in the phytoplankton community. The gap in the VIP scores between salinity (1.5510) and the following 
Table 2. Model fitting results of PLS analysis on biological, hydrographic and meteorological predictor variables $(x)$ and response variables $(y)$ representing diarrhetic shellfish toxin (DST) concentration in the plankton community (PLS-DST), abundances of Dinophysis acuta (PLS- $D$. acuta), D. acuminata (PLS-D. acuminata) and D. norvegica (PLS-D. norvegica). $k=$ component number; $\mathrm{R}^{2}{ }_{\mathrm{x}}=$ fraction of sum of squares of all the $x$ s explained by the component; $\mathrm{R}_{\mathrm{y}}^{2}=$ fraction of sum of squares of $y$ variable explained; $Q^{2}=$ fraction of the total variation of the $y$ s that can be predicted by the component

\begin{tabular}{|lccccc|}
\hline Model & $k$ & Eigenvalue & $\mathrm{R}^{2}{ }_{\mathrm{x}}$ & $\mathrm{R}_{\mathrm{Y}}^{2}$ & $Q^{2}$ \\
\hline PLS-DST & 1 & 4.269 & 0.305 & 0.705 & 0.569 \\
PLS- $D$. acuta & 1 & 3.876 & 0.277 & 0.659 & 0.434 \\
PLS- $D$. acuminata & 1 & 3.587 & 0.256 & 0.647 & 0.346 \\
PLS- $D$. norvegica & 1 & 3.767 & 0.269 & 0.66 & 0.419 \\
& & & & & \\
\hline
\end{tabular}

Table 3. Variable importance (VIP, variable influence on projection) and regression coefficients $\left(\right.$ Coeff $_{\mathrm{DST}}$ ) for PLS-DST (see text). Variables with VIP $>1$ are most influential for the model

\begin{tabular}{|lrr|}
\hline Variable & VIP & Coeff $_{\text {DST }}$ \\
\hline Dinophysis acuta & 1.9216 & 0.1230 \\
D. norvegica & 1.9051 & 0.1219 \\
D. acuminata & 1.8712 & 0.1197 \\
Salinity $8 \mathrm{~m}$ & 1.6815 & -0.1076 \\
Salinity $3 \mathrm{~m}$ & 1.5510 & -0.0992 \\
Atmospheric pressure & 1.0005 & 0.0640 \\
Silica & 0.9927 & -0.0635 \\
Current direction north $7 \mathrm{~m}$ & 0.9771 & -0.0625 \\
Nitrate and nitrite & 0.9668 & -0.0619 \\
Wind velocity & 0.9667 & -0.0619 \\
Wind direction & 0.8614 & 0.0551 \\
Ammonium & 0.8511 & 0.0545 \\
Precipitation & 0.8237 & -0.0527 \\
Air temperature & 0.6999 & 0.0448 \\
Current direction north $2 \mathrm{~m}$ & 0.5724 & -0.0366 \\
Current velocity south $2 \mathrm{~m}$ & 0.5640 & -0.0361 \\
Phosphate & 0.4871 & -0.0312 \\
Current velocity north $2 \mathrm{~m}$ & 0.4588 & 0.0294 \\
Current velocity north $7 \mathrm{~m}$ & 0.4125 & 0.0264 \\
Current direction south $2 \mathrm{~m}$ & 0.3218 & -0.0206 \\
Water temperature $8 \mathrm{~m}$ & 0.2622 & -0.0168 \\
Current velocity south $7 \mathrm{~m}$ & 0.1554 & -0.0099 \\
Chlorophyll a & 0.1404 & 0.0090 \\
Current direction south $7 \mathrm{~m}$ & 0.1374 & -0.0088 \\
Water temperature $3 \mathrm{~m}$ & 0.0097 & -0.0006 \\
& & \\
\hline
\end{tabular}

variables, starting with atmospheric pressure (1.0005), strongly suggests the importance of the Dinophysis species and salinity for the model relative to all other parameters. Therefore no second analysis was necessary to further investigate the ranking of the variables displaying VIP $<1.0006$.
Separate models were created where the numbers of the causative species (Dinophysis spp.) were left out from the predictor variables, i.e. the $x$ sphere, and the investigated period was divided into 3 sub-periods (October 10 to 16, October 18 to 26, October 28 to November 5), in order to see if the fluctuations in the concentration of DST in the plankton population could be addressed to any other environmental variable apart from the abundance of Dinophysis spp. These models unerringly generated salinity as the most important variable (data not shown). A plot of the abundance of the causative species versus the DST concentration in the plankton community $(\mathrm{n}=70)$ generated a linear relation of $\mathrm{R}^{2}=0.65$ (data not shown) and a calculation of OA eq cell-1 displayed a range from 0.24 to $38 \mathrm{pg}$.

Three separate models for each of the 3 different Dinophysis species were created (Table 2). In these models, each species was set as the response variable and the remaining parameters listed in Table 1 were the predictors. The 3 models were all reasonably good and explained $>64 \%$ of the variation in $y$ space. All 3 models yielded the highest VIP score for salinity, and the ranking between environmental variables was more or less indistinguishable for the 3 different species (Table 4), except for minor differences in the hierarchy of the least important variables. According to these 3 models (PLS-D. acuta, PLS-D. acuminata, PLSD. norvegica) the principal variables correlating with high abundances are the same for all 3 investigated species.

\section{Temporal relationships between the density of Dinophysis spp. cells and the toxicity of algal/mussel samples}

Concentration of DST in the plankton community and the number of Dinophysis spp. cells were low from October 10 to 16 (maximum average [n $=5$ ] $6.3 \mathrm{ng}$ OA eq $\mathrm{l}^{-1}$ and 2300 cells $\mathrm{l}^{-1}$, Fig. 4A). During the same period, toxicity of the mussels was initially above the limit concentration for marketing (160 $\mu \mathrm{g}$ OA eq $\mathrm{kg}^{-1}$ ) but the levels showed a decreasing trend, and on October 16 toxicity was below the limit value (Fig. 4B). An apparent increase in the number of Dinophysis spp. cells (average [n = 5] 17539 cells $\mathrm{l}^{-1}$ ) and the concentration of toxins in the plankton community (average $[\mathrm{n}=5] 15 \mathrm{ng}$ OA eq $\mathrm{l}^{-1}$ ) was observed on October 18. Toxicity of the mussels followed the same pattern, where the concentration of DST increased from approximately 90 to $225 \mu \mathrm{g}$ OA 
Table 4. Dinophysis spp. Variable importance (VIP, variable influence on projection) and regression coefficients (Coeff). Only variables with VIP $>1$ are shown

\begin{tabular}{|lcc|}
\hline Variable & VIP & Coeff $_{D . \text { acuta }}$ \\
\hline (A) PLS-D. acuta & & \\
Salinity 8 m & 1.2645 & -0.1522 \\
Atmospheric pressure & 1.1406 & 0.1373 \\
Salinity 3 m & 1.0955 & -0.1319 \\
Current direction north 7 m & 1.0522 & -0.1267 \\
& & \\
Variable & VIP & Coeff $_{D . \text { acuminata }}$ \\
\hline (B) PLS-D. acuminata & & \\
Salinity 8 m & 1.2485 & -0.1508 \\
Current direction north 7 m & 1.1117 & -0.1342 \\
Wind direction & 1.0918 & 0.1318 \\
Salinity 3 m & 1.0597 & -0.1280 \\
Atmospheric pressure & 1.0560 & 0.1275 \\
& & \\
Variable & VIP & Coeff $_{D . \text { norvegica }}$ \\
\hline (C) PLS-D. norvegica & & \\
Salinity 8 m & 1.2617 & -0.1408 \\
Current direction north 7 m & 1.2058 & -0.1346 \\
Wind direction & 1.0972 & 0.1225 \\
Salinity 3 m & 1.0719 & -0.1197 \\
Atmospheric pressure & 1.0456 & 0.1167 \\
& & \\
\hline
\end{tabular}

eq $\mathrm{kg}^{-1}$ from October 16 to 18 . This indicated a fast response in toxicity of mussels to the high Dinophysis spp. abundance. The concentration of DST in the mussels was further doubled from October 18 to 20 . No further increase in toxicity of mussels was detected during the rest of the period displaying high abundance of Dinophysis spp. The concentration of DST in mussels remained around $400 \mu \mathrm{g}$ OA eq $\mathrm{kg}^{-1}$ and appeared to have reached a maximum on October 22 (453 $\mu \mathrm{g}$ OA eq $\mathrm{kg}^{-1}$ ). On October 26, the number of Dinophysis spp. cells had declined (average $[n=5] 836$ cells $l^{-1}$ ). The concentrations of DST remained high in the plankton samples (15 ng OA eq $\mathrm{l}^{-1}$ ) for another $2 \mathrm{~d}$, but on October 28 the concentration of DST was again low, $<3 \mathrm{ng}$ OA eq $\mathrm{l}^{-1}$. The toxicity in the plankton community and the number of Dinophysis spp. cells were low (maximum average October 28 to November $5[\mathrm{n}=5] 1.8 \mathrm{ng}$ OA eq $\mathrm{l}^{-1}$ and 120 cells $\mathrm{l}^{-1}$ ) throughout the rest of the investigated period, i.e. until November 5, whereas the toxicity of the mussels remained high (maximum average [n =5] on October 28, $479 \mu \mathrm{g} \mathrm{OA} \mathrm{eq} \mathrm{kg}^{-1}$ ) and no obvious trend towards a decrease during this period was observed.

\section{DISCUSSION}

It is evident that the Dinophysis spp. population did not originate within the study area itself. Considering an approximate growth rate of $0.5 \mathrm{~d}^{-1}$ (Carlsson et al. 1995), the number of cells present on October 16 was not high enough to justify the increase recorded $2 \mathrm{~d}$ later (Fig. 2D). In contrast, the peaks recorded on October 18 to 24 were due to surface water inflow from the Skagerrak, which contained high abundances of Dinophysis spp. The influx of surface water could be confirmed by a sharp drop in salinity and absence of a pycnocline between 3 and $8 \mathrm{~m}$ on October 18 (Fig. 2A,B). The disappearance of Dinophysis spp. coincided with a third body of water, characterized by high salinity and $\mathrm{NO}_{2}{ }^{-}-\mathrm{NO}_{3}{ }^{-}$concentration (Fig. 3).

High densities of Dinophysis spp. have previously been shown to be a result of advection (Lassus et al. 1993, Reguera et al. 1995). Also, previous blooms of other potentially harmful algae in near-shore areas

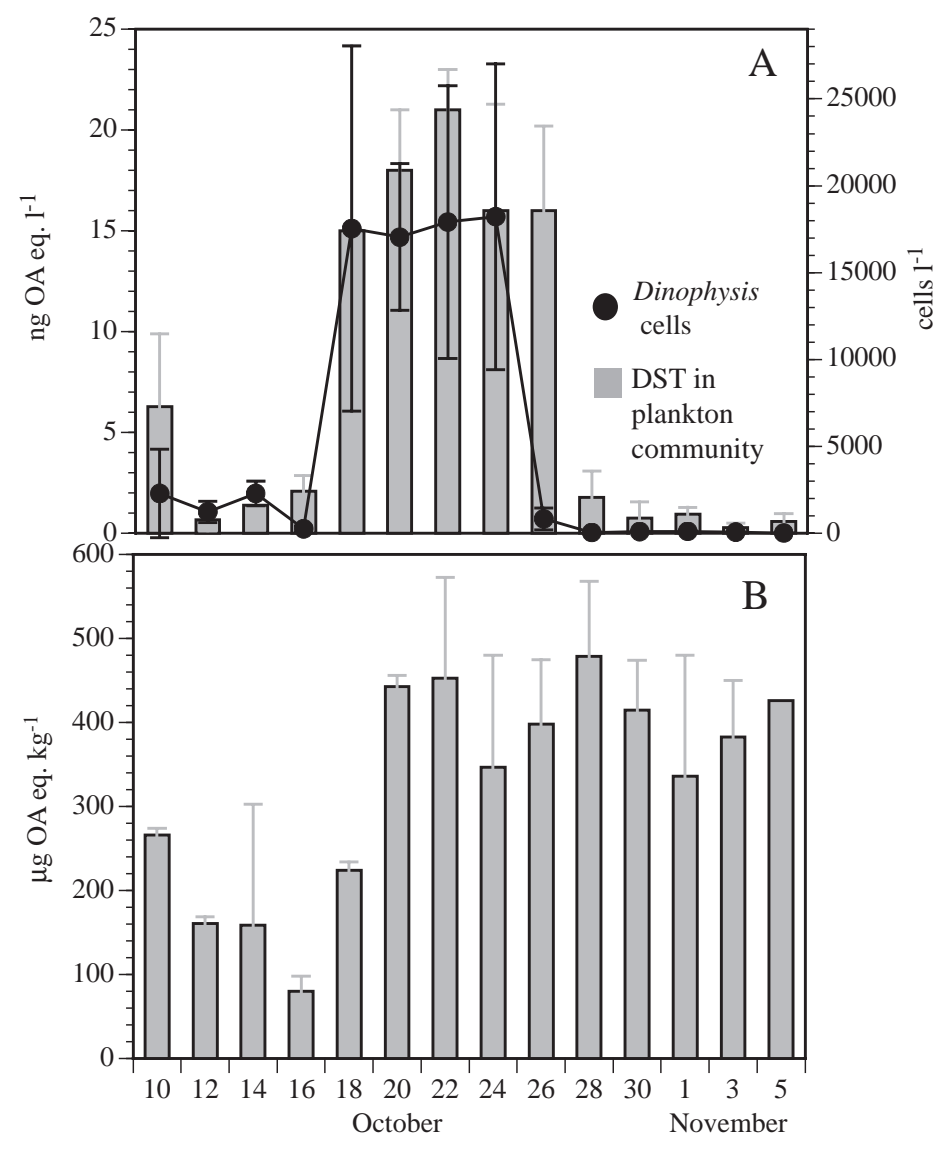

Fig. 4. (A) Concentration of diarrhetic shellfish toxins (DST) in the plankton community (ng okadaic acid equivalents per liter: ng OA eq $\mathrm{l}^{-1}$ ) and abundances of Dinophysis spp. (cells $\mathrm{l}^{-1}$ ). (B) Concentration of DST in mussels ( $\mu \mathrm{g}$ OA eq $\mathrm{kg}^{-1}$ ) 
along the Swedish west coast have been associated with water exchange. A population of Gyrodinium aureolum Hulburt in Gullmar Fjord in 1982 increased too fast to be a result of local growth. The bloom persisted for approximately $3 \mathrm{wk}$, until water exchange ended its presence in the area (Lindahl 1983).

Interpretation of relationships between environmental and oceanographic parameters and the abundance of particular microalgal species is particularly difficult if the algal population in question constitutes a minor fraction of the total algal biomass. Previous studies have shown that the Dinophysis community usually represents a small fraction of the phytoplankton assemblage, even at cell densities of several thousand cells per litre on occasions that would be termed a bloom (Maestrini 1998, and references therein). However, in this study Dinophysis was the dominating genus for $8 \mathrm{~d}$ (Fig. 2C,D) and hence the outcome of the multivariate analysis, for which a clear negative relationship between salinity and Dinophysis spp. cell numbers/algal toxicity was found, is very well supported.

A strong correlation between Dinophysis spp. abundances and low salinity (Giacobbe et al. 1995, Perperzak et al. 1996, Soudant et al. 1997) or stratified water (Delmas et al. 1992, Lassus et al. 1993, Reguera et al. 1995) has previously been demonstrated. Our results, generated from data collected in a narrow spatial and temporal scale, is a confirmation of what previously has been observed at a larger scale, either through analyses of monitoring data or through largerscale sampling. Several studies manifest the importance of stratification for high abundances of Dinophysis spp. Dinophysis will rarely reach high numbers in mixed water masses. Delmas et al. (1992) reasoned that stratification through temperature differences favours high abundances and accumulation of Dinophysis, but stratified water in terms of salinity would not have the same effect. In contrast, our results suggest that a favourable environment for high Dinophysis abundance can be established also through a salinity gradient.

We did not find any positive correlation between inorganic nutrients and the numbers of Dinophysis spp. Several other investigations indicate the same absence of correlation between dissolved inorganic nutrients and number of Dinophysis cells (Delmas et al. 1992, Lindahl \& Andersson 1996, Blanco et al. 1998, Aubry et al. 2000, Smayda \& Reynolds 2001). Termination of Dinophysis blooms despite increased availability of nutrients has previously been reported (Perperzak et al. 1996), but there are also reports of $D$. cf. acuminata growth in conjunction with high concentrations of inorganic nitrogen (Lassus et al. 1993).

It has been shown that phytoplankton, including toxic species, has the capability to use dissolved organic matter as a nutrient source (e.g. Carlsson \& Granéli 1998). Due to the difficulty of establishing cultures of Dinophysis spp., the importance of DOM for their growth is unknown. Further, the potential for Dinophysis spp. to adapt a mixotrophic mode of life has been demonstrated (Granéli \& Carlsson 1998). Also, some studies show a close relationship between bacterial cells, cyanobacteria and Dinophysis spp. growth (Maestrini 1998, and references therein). If possible, it would be advantageous if future studies addressing the issue of which environmental parameter influences Dinophysis spp. growth include DOM, the number of potential prey, bacterial and cyanobacteria counts in addition to all the parameters examined in this study.

Several long-term studies and analyses of data from monitoring programmes, e.g. along the Norwegian coast and in the Mediterranean, have revealed seasonal distribution of different Dinophysis species (Dahl et al. 1995, Aubry et al. 2000). It has also been demonstrated that when $D$. acuta and $D$. acuminata coexist, they occupy different water masses (Reguera et al. 1995). This implies that different Dinophysis species thrive under different environmental conditions. In this study, conducted on a small spatio-temporal scale, the 3 dominant species D. acuta, D. acuminata and $D$. norvegica all had the same strong inverse correlation to salinity (Table 4). The species were present at the same time and in roughly the same numbers (Fig. 2D). Their similar abundances during the same oceanographic settings contrast to other studies.

We have assumed that the correlation between numbers of Dinophysis cells and the DST concentration of the plankton community reflects the toxin concentration per cell. The concentration varied from 0.24 to $38.8 \mathrm{pg} \mathrm{OA} \mathrm{eq} \mathrm{cell}{ }^{-1}$ and was in the same range as in previous studies of Dinophysis spp. (Masselin et al. 1992, Andersen et al. 1996, Johansson et al. 1996). Although there was a rather strong relationship between the abundance of Dinophysis spp. and concentration of DST in the phytoplankton community $\left(\mathrm{R}^{2}=\right.$ 0.65), the correlation suggests that there ought to be additional factors influencing cellular toxicity. Whether this large variability in the assumed cellular toxin concentration can be attributed to specific Dinophysis clones or the effects of environmental factors on the physiological state of the algae still remains to be solved. Salinity, which emerged as the most important environmental variable in relation to DST concentration in the plankton community, was according to our PLS model (Table 3) also the most important variable in relation to the causative species (Table 4). Hence we believe that low salinity, or stratified water as discussed above, is important for Dinophysis abundances but not necessarily the factor promoting high DST concentrations per cell. 
As expected, the concentration of DST in the plankton community increased on October 18 simultaneously with the peak in cell density of the causative species (Fig. 4A). The high abundance persisted for $8 \mathrm{~d}$ and terminated after October 24. The concentration of DST in the plankton community was unexpectedly high on October 26, despite the low numbers of Dinophysis spp. cells (Figs. 2D \& 4A). On October 28, a new type of water characterized by higher salinity and higher concentrations of $\mathrm{NO}_{2}{ }^{-}-\mathrm{NO}_{3}{ }^{-}$, again replaced the surface water of the area (Fig. 3). By then, the concentration of DST in the plankton community had also decreased. The persistence of toxicity in the plankton community despite the absence of Dinophysis is puzzling. One possible explanation could be the transfer of toxins through the foodweb. For example, laboratory experiments have demonstrated that some copepods consume D. acuminata while others detest this species (Carlsson et al. 1995). Hence, it is reasonable to assume that grazers feeding upon Dinophysis have concentrated DST, and the DST recorded from the plankton community was actually from copepods and/or faecal pellets. The presence of inhibitors of PP2A other than diarrhogenic toxins such as nodularin and microcystin produced by filamentous cyanobacteria could also explain the confounding levels of DST recorded from the plankton community. However, no filamentous cyanobacteria could be observed in the plankton samples and these toxin-producing species are very seldom encountered in the area, as stated in phytoplankton monitoring programmes for the Swedish west coast (Edler 1995, Hernroth \& Kuylenstierna 1998).

The immediate increase in the toxicity of mussels in response to the presence of Dinophysis was also somewhat unexpected. Previous studies, mainly modelling of monitoring data, have demonstrated that mussel intoxication occurs 2 to $3 \mathrm{wk}$ after Dinophysis spp. is first encountered in the water mass (Kat 1983, Sampayo et al. 1990). However, faster temporal correlation between D. fortii Pavillard and DST concentration in the mussel Mytilus galloprovincialis Lam. has been reported (Sidari et al. 1998). It has also been observed that mussels accumulate a higher concentration of DST when concentrations of non-toxic accompanying species are low in the water mass (Sampayo et al. 1990, Haamer 1995). In this study, the mussels within the farm site had observable concentrations of DST since March $(<30$ to $164 \mu \mathrm{g} \mathrm{OA} \mathrm{kg}{ }^{-1}$ data from the national monitoring programme), which means Dinophysis spp. occurrence was not a 'new' feature of the year. Furthermore, the chl a concentration was very low at the onset of the peak in Dinophysis abundance (Fig. 2C,D), suggesting very few accompanying species, which could further explain the fast accumulation of DST in mussels.

No clear trend of detoxification of the mussels was observed after October 28 when the Dinophysis spp. population had declined and the toxicity in the plankton community again was very low. It has been suggested in several papers that the main factor affecting the rate of depuration of DST in mussels is the quantity of non-toxic food available for mussels to feed upon (Haamer et al. 1990b, Sampayo et al. 1990, MarcaillouLe Baut et al. 1993, Poletti et al. 1996, Blanco et al. 1999). In this study, the low chl a observed in the water after the Dinophysis spp. peak suggests that food sources for the mussels were scarce, which could explain the absence of depuration. However, experimental testing of the effects of food on depuration of DST in mussels contradicts the importance of this factor for depuration (S. Svensson unpubl.).

\section{Conclusions}

This study has clearly demonstrated that large-scale hydrographical processes such as advection are important for the distribution and abundance of toxic Dinophysis spp. In accordance with some previous studies, we found that Dinophysis thrives in surface waters characterized by low salinity. We also found that the 3 species $D$. acuta, $D$. acuminata and $D$. norvegica coexisted under the same conditions. The inflow of offshore surface water to near-shore areas along the Swedish west coast was dependent on wind direction. Hence, this meteorological parameter, together with plankton sampling, should be important for modelling and predictions about the abundance of Dinophysis in various locations along the coast. Ideally, these models could then be used as early warning systems for the onset of toxic blooms.

At present, the frequency of phytoplankton monitoring is once every month at 6 different stations along a $200 \mathrm{~km}$ stretch of the Swedish west coast. The data obtained in this study show that with such long intervals, large blooms could pass without ever being noticed. In light of this, the purpose of, and what can be achieved by, monitoring phytoplankton once a month is questionable. Also, the rapid increase in DST concentration in mussels in response to Dinophysis further emphasizes the importance of frequent analyses of toxins in commercially grown mussels.

Acknowledgements. We are thankful to Dr. Anne-Marie Larsson, Department of Oceanography, Johan Burman, Department of Marine Geology, Dr. Melissa McQuoid, Professor Inger Wallentinus, Marine Botany, Göteborg University, and 3 anonymous reviewers for constructive and valuable criticism of the manuscript. We also thank Zbigniew Uggla, Tjärnö Vattenbruk, for letting us use the farm site. This work was funded by grants from the Foundation for Strategic Environmental Research (SuCoZoMa, Dnr 95005), Adlerbertska forskningsfonden and C. F. Lundströms Stiftelse. 


\section{LITERATURE CITED}

Andersen P, Hald B, Emsholm H (1996) Toxicity of Dinophysis acuminata in Danish coastal waters. In: Yasumoto $\mathrm{T}$, Oshima Y, Fukuyo Y (eds) Harmful and toxic algal blooms. Intergovernmental Oceanographic Commission of UNESCO, Paris, p 281-284

Aubry FB, Berton A, Bastianini M, Bertaggia R, Baroni A, Socal G (2000) Seasonal dynamics of Dinophysis in coastal waters of the NW Adriatic Sea (1990-1996). Bot Mar 43: 423-430

Blanco J, Moroño Á, Pazos Y, Maneiro J, Mariño J (1998) Trends and variations of the abundance of main PSP and DSP producing species in the Galician Rias: environmental and biological influences. In: Reguera B, Blanco J, Fernández M, Wyatt T (eds) Harmful algae. Xunta de Galicia and Intergovernmental Oceanographic Commission of UNESCO, Santiago de Compostela, p 204-207

Blanco J, Fernández ML, Míguez A, Moroño A (1999) Okadaic acid depuration in the mussel Mytilus galloprovincialis: one- and two-compartment models and the effect of environmental conditions. Mar Ecol Prog Ser 176:153-163

Carlsson P, Granéli E (1998) Utilization of dissolved organic matter (DOM) by phytoplankton, including harmful species. In: Anderson DM, Cembella AD, Hallegraeff GM (eds) Physiological ecology of harmful algal blooms. Springer-Verlag, Berlin, p 509-524

Carlsson P, Granéli E, Finenko G, Maestrini S (1995) Copepod grazing on a phytoplankton community containing the toxic dinoflagellate Dinophysis acuminata. J Plankton Res $17: 1925-1938$

Carmody EP, James KJ, Kelly SS (1996) Dinophysistoxin-2: the predominant diarrhoetic shellfish toxin in Ireland. Toxicon 34:351-359

Dahl E, Rogstad A, Aune T, Hormazabal V, Underdal B (1995) Toxicity of mussels related to occurrence of Dinophysis species. In: Lassus P, Arzul G, Erard E, Gentien P, Marcaillou C (eds) Harmful marine algal blooms. Lavoisier, Paris, p 783-788

Daranas AD, Norte M, Fernández JJ (2001) Toxic marine microalgae. Toxicon 39:1101-1132

Delmas D, Herbland A, Maestrini S (1992) Environmental conditions which lead to increase in cell density of the toxic dinoflagellates Dinophysis spp. in nutrient-rich and nutrient-poor waters of the French Atlantic coast. Mar Ecol Prog Ser 89:53-61

Edler L (1995) Fytoplankton årsrapport 1995. Report to the Water Quality Association of the Bohus Coast, Uddevalla (in Swedish)

Eriksson L, Johansson E, Kettanneh-Wold N, Wold S (1999) Introduction to multi and megavariate data analysis using projection methods (PCA \& PLS). Umetrics, Umeå

Fujiki H, Suganuma M, Suguri H, Yoshizawa S and 7 others (1988) Diarrhetic shellfish toxin, dinophysistoxin-1, is a potent tumour promoter on mouse skin. Jpn J Cancer Res 79:1089-1093

Giacobbe MG, Oliva F, La Ferla R, Puglisi A, Crisafi E, Maimone G (1995) Potentially toxic dinoflagellates in Mediterranean waters (Sicily) and related hydrobiological conditions. Aquat Microb Ecol 9:63-68

Granéli E, Carlsson P (1998) The ecological significance of phagotrophy in photosynthetic flagellates. In: Anderson DM, Cembella AD, Hallegraeff GM (eds) Physiological ecology of harmful algal blooms. Springer-Verlag, Berlin, p 539-577

Granéli E, Johansson N, Panosso R (1998) Cellular toxin contents in relation to nutrient conditions for different groups of phycotoxins. In: Reguera B, Blanco J, Fernández M, Wyatt T (eds) Harmful algae. Xunta de Galicia and Intergovernmental Oceanographic Commission of UNESCO, Santiago de Compostela, p 321-324

Grasshoff K, Erhardt M, Kremling K (1983) Methods of seawater analyses. Verlag Chemie, Weinheim

Haamer J (1995) Presence of the phycotoxin okadaic acid in mussels (Mytilus edulis) in relation to nutrient composition in Swedish coastal water. J Shellfish Res 14:209-216

Haamer J, Andersson PO, Lindahl O, Lange S, Li XP, Edebo L (1990a) Geographic and seasonal variation of okadaic acid content in farmed mussels, Mytilus edulis Linnaeus, 1758, along the Swedish west coast. J Shellfish Res 9:103-108

Haamer J, Andersson PO, Lindahl O, Lange S, Li XP, Edebo L (1990b) Effects of transplantation and reimmersion of mussels Mytilus edulis Linnaeus, 1758, on their contents of okadaic acid. J Shellfish Res 9:109-112

Hallegraeff G (1995) Harmful algal blooms: a global overview. In: Hallegraeff GM, Anderson DM, Cembella $\mathrm{AD}$ (eds) Manual on harmful marine microalgae. IOC Manuals and Guides No 33, UNESCO, Paris, p 1-22

Hamasaki K, Horie M, Tokimitsu S, Toda T, Taguchi S (2001) Variability in toxicity of the dinoflagellate Alexandrium tamarense isolated from Hiroshima Bay, western Japan, as a reflection of changing environmental conditions. J Plankton Res 23:271-278

Hernroth B, Kuylenstierna M (1998) Fytoplankton analyser 1998. Report to the Water Quality Association of the Bohus Coast, Uddevalla (in Swedish)

Jeffrey S, Humphrey G (1975) New spectrophotometric equations for determining chlorophylls $a, b, c 1$ and $c 2$ in higher plants, algae and natural phytoplankton. Biochem Physiol Pflanz 167:191-194

Johansson N, Granéli E, Yasumoto T, Carlsson P, Legrand C (1996) Toxin production by Dinophysis acuminata and $D$. acuta cells grown under sufficient and deficient conditions. In: Yasumoto T, Oshima Y, Fukuyo Y (eds) Harmful and toxic algal blooms. Intergovernmental Oceanographic Commission of UNESCO, Paris, p 277-280

John EH, Flynn KJ (2000) Growth dynamics and toxicity of Alexandrium fundyense (Dinophyceae): the effect of changing N:P supply ratios on internal toxin and nutrient levels. Eur J Phycol 35:11-23

Kat M (1983) Dinophysis acuminata blooms in the Dutch coastal area related to diarrhetic mussel poisoning in the Dutch Wadden Sea. Sarsia 68:81-84

Kautsky N, Wallentinus I (1980) Nutrient release from a Baltic Mytilus-red algal community. Ophelia(Suppl)1:17-30

Kollberg S (1999) Beskrivning av den svenska musselnäringen. Vattenbrukarnas Riksförbund, Göteborg (in Swedish)

Kumagai M, Yanagi T, Murata M, Yasumoto T, Kat M, Lassus P, Rodriguez-Vazquez JA (1986) Okadaic acid as the causative toxin of diarrhetic shellfish poisoning in Europe. Agric Biol Chem 50:2853-2857

Larsson AM (1984) Hydrographical and chemical observations in a coastal area with mussel farming, western Sweden. Oceanografiska Institutionen, Göteborg University, Göteborg

Larsson AM (1986) Blue mussel sea farming-effects on water quality. Vatten 41:218-224

Lassus P, Proniewski F, Maggi P, Truquet P, Bardouil M (1993) Wind-induced toxic blooms of Dinophysis cf. acuminata in the Antifer area. In: Smayda TJ, Shimizu Y (eds) Toxic phytoplankton blooms in the sea. Elsevier, New York, p 519-523

Lee JS, Ganagi T, Kenna R, Yasumoto T (1987) Fluorometric determination of diarrhetic shellfish toxins by high- 
performance liquid chromatography. Agric Biol Chem 51: $877-881$

Lindahl O (1983) On the development of a Gyrodinium aureolum occurrence on the Swedish west coast in 1982. Mar Biol 77:143-150

Lindahl O (1995) Long term studies of primary phytoplankton production in the Gullmar fjord, Sweden. In: Skjoldal HR, Hopkins C, Erikstad KE, Leinaas HP (eds) Ecology of fjords and coastal waters. Elsevier Science, Amsterdam, p 105-112

Lindahl O, Andersson B (1996) Environmental factors regulating the occurrence of Dinophysis spp. in the Koljöfjord, Sweden. In: Yasumoto T, Oshima Y, Fukuyo Y (eds) Harmful and toxic algal blooms. Intergovernmental Oceanographic Commission of UNESCO, Paris, p 269-272

Lindegarth M (1997) Sammanställning och tolkning av de kontinuerliga mätningarna av okadasyrahalter längs den svenska västkusten. Bohuskustens Vattenvårdsförbund, Göteborg (in Swedish)

Maestrini SY (1998) Bloom dynamics and ecophysiology of Dinophysis spp. In: Anderson DM, Cembella AD, Hallegraeff GM (eds) Physiological ecology of harmful algal blooms. Springer-Verlag, Berlin, p 243-265

Marcaillou-Le Baut C, Bardin B, Bardouil M, Bohec M, Dean LL, Masselin P, Truquet P (1993) DSP depuration rates of mussels reared in a laboratory and an aquaculture pond. In: Smayda TJ, Shimizu Y (eds) Toxic phytoplankton blooms in the sea. Elsevier Science, Amsterdam, p 531-535

Masselin P, Lassus P, Bardouil M (1992) High-performance liquid-chromatography analysis of diarrhetic toxins in Dinophysis spp. from the French coast. J Appl Phycol 4(4): 385-389

Murakami Y, Oshima Y, Yasumoto T (1982) Identification of okadaic acid as a toxic component of a marine dinoflagellate Prorocentrum lima. Bull Jpn Soc Sci Fish 48:69-72

Peperzak L, Snoeijer GJ, Dijkema R, Gieskes WWC and 5 others (1996) Development of a Dinophysis acuminata bloom in the River Rhine plume (North Sea). In: Yasumoto T, Oshima Y, Fukuyo Y (eds) Harmful and toxic algal blooms. Intergovernmental Oceanographic Commission of UNESCO, Paris, p 273-276

Poletti R, Viviani R, Casadei C, Lucentini L, Funari E, Draisci $\mathrm{R}$ (1996) Decontamination dynamics of mussels naturally contaminated with diarrhetic toxins relocated to a basin of the Adriatic Sea. In: Yasumoto T, Oshima Y, Fukuyo Y (eds) Harmful and toxic algal blooms. Intergovernmental Oceanographic Commission of UNESCO, Paris, p 429-432

Editorial responsibility: Otto Kinne (Editor),

Oldendorf/Luhe, Germany
Reguera B, Bravo I, Fraga S (1995) Autoecology and some life history stages of Dinophysis acuta Ehrenberg. J Plankton Res 17:999-1015

Rodhe J (1987) The large scale circulation in the Skagerrak; interpretation of some observations. Tellus 39:245-253

Sampayo MAdeM (1993) Trying to cultivate Dinophysis spp. In: Smayda TJ, Shimizu Y (eds) Toxic phytoplankton blooms in the sea. Elsevier Science, Amsterdam, p 807-810

Sampayo MAdeM, Alvito P, Franca S, Sousa I (1990) Dinophysis spp. toxicity and relation to accompanying species. In: Granéli E, Sundström B, Edler L, Anderson DM (eds) Toxic marine phytoplankton. Elsevier Science, New York, p 215-220

Sidari L, Nichetto P, Cok S, Sosa S, Tubaro A, Honsell G, Della Loggia R (1998) Phytoplankton selection by mussels, and diarrhetic shellfish poisoning. Mar Biol 131:103-111

Smayda TJ, Reynolds CS (2001) Community assembly in marine phytoplankton: application of recent models to harmful dinoflagellate blooms. J Plankton Res 23:447-461

Song L, Sano T, Li R, Watanabe MM, Liu Y, Kaya K (1998) Microcystin production of Microcystis viridis (cyanobacteria) under different culture conditions. Phycol Res 46 (Suppl):19-23

Soudant D, Beliaeff B, Thomas G (1997) Explaining Dinophysis cf. acuminata abundance in Antifer (Normandy, France) using dynamic linear regression. Mar Ecol Prog Ser 156:67-74

Utermöhl H (1958) Zur Vervollkommnung der quantitativen Phytoplankton-Methodik. Mitt Int Ver Limnol 9:1-38 (in German)

Vieytes MR, Fontal OI, Leira F, Baptista de Sousa JMV, Botana LM (1997) A fluorescent microplate assay for diarrhetic shellfish toxins. Anal Biochem 248:258-264

Willén T (1962) Studies on the phytoplankton of some lakes connected with or recently isolated from the Baltic. Oikos 13:169-199

Wold S, Albano C, Dunn WJ III, Edlund U and 6 others (1984) Multivariate data analysis in chemistry. In: Kowalski BR (ed) Chemometrics - mathematics and statistics in chemistry. Reidel Publishing, Dordecht, p 1-79

Yasumoto T, Oshima Y, Sugawara W, Fukuyo Y, Oguri H, Igarashi T, Fujita N (1980) Identification of Dinophysis fortii as the causative organism of diarrhetic shellfish poisoning. Bull Jpn Soc Sci Fish 46:1405-1411

Yasumoto T, Murata M, Oshima Y, Sano M, Matsumoto GK, Clardy J (1985) Diarrhetic shellfish toxins. Tetrahedron 41: 1019-1025

Submitted: October 10, 2001; Accepted: May 24, 2002

Proofs received from author(s): August 22, 2002 